\title{
Effects of Phenol Addition on Oil Extraction from Moroccan Oil Shale by Supercritical Toluene
}

\author{
A. Abourriche ${ }^{a,}$, M. Oumam ${ }^{b}$, A. Benhammou ${ }^{a}$, M. Mouiya ${ }^{a}$, Y. El hafiane ${ }^{a}$, Y. Abouliatim ${ }^{a}$, \\ L. Nibou ${ }^{a}$, H. Hannache ${ }^{b}$, M. Birot ${ }^{c}$, R. Pailler ${ }^{d}$ and R. Naslain ${ }^{d}$ \\ a'Laboratoire Matériaux, Procédés et Environnement, École Nationale des Sciences Appliquées, B.P. 63 \\ 46000 Safi, Morocco \\ ${ }^{b}$ Laboratoire des Matériaux Thermostructuraux, Faculté des Sciences Ben M'sik, B.P. 7955 Casablanca, \\ Morocco \\ 'Univ. Bordeaux, Institut des Sciences Moléculaires, UMR 5255, F-33405 Talence, France \\ dUniv. Bordeaux, Laboratoire des Composites Thermostructuraux, UMR 5801, F-33600 Pessac, France
}

\begin{abstract}
In the present work, the effect of phenol on the supercritical extraction of the organic matter from Tarfaya's oil shale with toluene was evaluated. The experimental results showed clearly that phenol had a significant effect on the yield and the composition of the oils obtained. Moreover, it was shown that phenol was a very efficient modifier for oil shale, giving a good yield of recovery and a suitable maturation of the organic matter. The pitches prepared by mixing phenol and toluene contain more aromatics and have a high char yield at $950{ }^{\circ} \mathrm{C}$ compared to those obtained by extraction with supercritical toluene alone.
\end{abstract}

Keywords: Oil shale, Supercritical extraction, Toluene, Phenol, Pitch.

\section{INTRODUCTION}

Oil shale has been considered for a long time as a great economic hope for those countries that possess large reserves. Thus, programs to operate oil shale as an energy source were launched by several countries such as Scotland, Australia, France and China [1-4]. These programs eventually demonstrated that more research is needed to make the oil produced cost effective and competitive against conventional petroleum.

Besides, oil shale has some potential for the manufacturing of synthetic products such as cement, calcium, alumina, pitches, carbon adsorbents, zeolites, carbon fibers and other chemicals [5-10]. As a result, in recent years many studies have been carried out on methods for oil extraction, such as pyrolysis by conventional heating or under microwave irradiation, extraction with solvents under sub and supercritical conditions, or combustion in fluidized bed reactors [1317]. Particularly, it has been demonstrated that the extraction yield and the quality of oils extracted depend on several parameters (nature of solvent, modifier, temperature, pressure, duration of treatment, heating rate, grain size...).

*Correspondence Address to this author at the Laboratoire Materiaux, Procédés et Environnement, École Nationale des Sciences Appliquées, B.P. 6346000 Safi, Morocco; Tel: 00212 64456721; Fax: 0021224668012;

E-mail: krimabou@hotmail.com
The effect of modifiers on the performance of supercritical extraction has been reviewed by several authors [18-20]. Solvents used were pentane for the extraction of food products [21], polycyclic aromatic hydrocarbons [22], and acetone [23] or hexane [24] to extract pesticide residues. Other authors have also used the reagents in order to degrade the solute molecules [25-27]. Lanças et al. [21] have studied the effect of certain solvents (acetone, hexane, methanol) on the extraction of the herbicide Diuron from sugar cane and orange samples with supercritical $\mathrm{CO}_{2}$. They concluded that methanol enhanced significantly the extraction yield compared to other modifiers.

Meanwhile, Oliveira et al. [28] reported that the addition of organic solvents in the extraction of oil shale with supercritical water improved the yield and quality of the extracted oils. Earlier studies had also shown that the addition of $\mathrm{CO}$ or $\mathrm{H}_{2}$ when extracting oil from shale and coal with water improved the efficiency and quality of the oils produced [29, 30].

In this work, we chose phenol as modifier in oil extraction from Moroccan oil shale with supercritical toluene. This choice was dictated by the thermal stability of phenol, due to intermolecular hydrogen bonds. Besides, the highly reactive hydroxyl group could react with some organic functions present in the oil shale. The objective was to investigate the effect of phenol on the yield and the composition of the oil obtained by extraction with supercritical toluene. 


\section{EXPERIMENTAL}

\subsection{Materials}

The oil shale used in this work was from the Tarfaya deposit located in the South of Morocco. This deposit consists of several layers that are in turn subdivided in sub-layers, each having a different amount of organic matter. The samples were obtained from the $\mathbf{R}_{\mathbf{3}}$ sublayer, which is characterized by its high content of organic matter [31]. The chemical composition of the $R_{3}$ sub-layer is given in reference [32].

The carbonate-free oil shale $(\mathbf{R H})$ was obtained by dissolution of carbonates with $\mathrm{HCl}[33,34]$. The powdered $\mathbf{R}_{\mathbf{3}}$ shale $(20 \mathrm{~g}$, grain size $0.063-0.08 \mathrm{~mm}$ ) and $80 \mathrm{~mL}$ of concentrated $\mathrm{HCl}(7 \mathrm{M})$ were introduced in an Erlenmeyer. The mixture was then subjected to magnetic stirring for $4 \mathrm{~h}$. The $\mathrm{CO}_{2}$ produced was trapped by bubbling in a solution of barium hydroxide. After filtration, the solid residue (referred to as $\mathbf{R H}$ ) was washed carefully with distilled water, dried at $100{ }^{\circ} \mathrm{C}$ and stocked in a sealed plastic bag.

\subsection{Methods}

\subsubsection{Preparation of the Pitches}

Supercritical extraction of the sample RH $(10 \mathrm{~g})$ with toluene as solvent was conducted in a $120 \mathrm{~mL}$ stainless steel autoclave equipped with a stirrer and heated in a tubular furnace whose temperature and heating rate were controlled. The temperature of extraction was $390{ }^{\circ} \mathrm{C}$ with a heating rate of $16{ }^{\circ} \mathrm{C} \mathrm{min}{ }^{-1}$ [35]. The maximum pressure reached during this treatment of $120 \mathrm{~min}$ was $8 \mathrm{MPa}$. After cooling to room temperature, the mixture was extracted in a Soxhlet apparatus with chloroform for $12 \mathrm{~h}$. After removing the solvent under reduced pressure, the organic material was dried for $12 \mathrm{~h}$ at $40{ }^{\circ} \mathrm{C}$ and weighed. The recovered oil was treated with $n$-hexane in a $1 / 10$ oil to solvent mass ratio [36] in order to precipitate the highmolecular fraction (asphaltenes) that constitutes the pitch. After stirring for $12 \mathrm{~h}$, the two fractions, soluble (maltenes) and insoluble (asphaltenes), were separated by filtration through Whatman paper and then dried for $12 \mathrm{~h}$ at $40{ }^{\circ} \mathrm{C}$ and $80{ }^{\circ} \mathrm{C}$, respectively. The scheme of the autoclave is shown in Figure 1.

\subsubsection{Preparation of Carbon Fibers}

The pitch was melted at $180{ }^{\circ} \mathrm{C}$ in a laboratorymade spinning device, equipped with a single spinneret and a filter to remove solid particles from the melt [37]. After extrusion and mechanical stretching, the fiber was thermoset by slow heating in dry air at atmospheric pressure to temperatures in the range of $60-280{ }^{\circ} \mathrm{C}$. The oxidized fibers were pyrolyzed under nitrogen flow with the temperature being progressively raised up to $950{ }^{\circ} \mathrm{C}$ at a heating rate of $5^{\circ} \mathrm{C} \min ^{-1}[38]$.

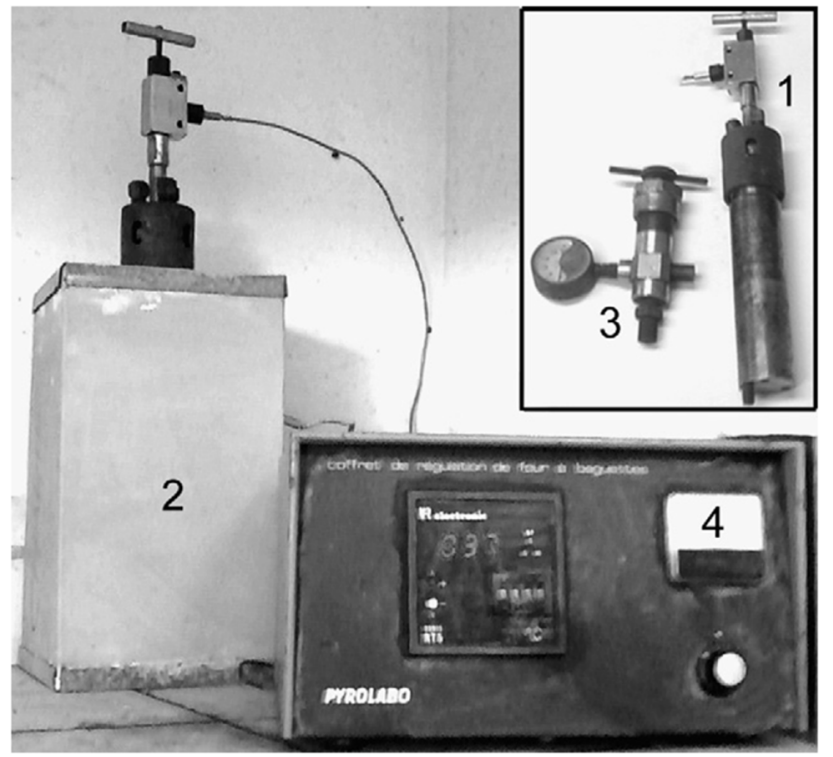

Figure 1: Schematic diagram of the apparatus used for supercritical extraction: (1) reactor; (2) furnace; (3) pressure gauge; (4) thermocouple; (5) regulator.

\subsection{Analyses}

Elemental analysis was performed at the Service Central d'Analyse du CNRS (France).

The analyses by X-ray photoelectron spectroscopy (ESCA-XPS) were carried out in an Escalab VG220i$\mathrm{XL}$ apparatus.

The electron probe X-ray microanalysis (EPMA) was carried out in a Cameca SX 100 apparatus.

IR spectra were recorded between 400 and 4000 $\mathrm{cm}^{-1}$ with a Nicolet 205 FT-IR spectrometer by summing 32 scans at $2 \mathrm{~cm}^{-1}$ resolution. Pellets were prepared by dispersing $2 \mathrm{mg}$ of sample into $198 \mathrm{mg}$ of $\mathrm{KBr}$.

Thermogravimetry (TG) was performed with a TGS2 Perkin-Elmer analyzer under high purity argon flow $\left(40 \mathrm{~mL} \mathrm{~min}{ }^{-1}\right)$. Samples of about $12 \mathrm{mg}$ were heated from 50 to $950{ }^{\circ} \mathrm{C}$ at a heating rate of $5{ }^{\circ} \mathrm{C} \mathrm{min}^{-1}$.

The surface areas of the fibers were measured by nitrogen adsorption at $77 \mathrm{~K}$ with a Micromeritics Flowsorb II 2300 instrument using the BET method. Before adsorption measurements, the samples were outgassed at $160{ }^{\circ} \mathrm{C}$ for $24 \mathrm{~h}$. 
Scanning electron microscopy (SEM) micrographs were taken with a Hitachi TM-1000 microscope. Fragments of about $0.5 \mathrm{~cm}^{2}$ cut from the corresponding samples were mounted on a carbon tab, which ensured a good conductivity. A thin layer of gold-palladium was sputtered prior to analysis.

Size exclusion chromatography (SEC) was carried out on a Waters analytical system (pump 510, refractometer 410 and UV/visible detector 486) with

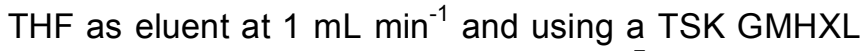
column with mixed porosity $1500-10^{7} \AA$. Relative average molecular weights were calculated with a cubic 12-point calibration curve obtained from monodisperse polystyrene standards.

${ }^{1} \mathrm{H}$ NMR spectra were recorded on a Bruker AC 250 $(250 \mathrm{MHz})$ spectrometer. The samples were placed in $5 \mathrm{~mm}$-ID tubes with deuterated chloroform $\left(\mathrm{CDCl}_{3}\right)$ as solvent. The chemical shifts are given in ppm relative to TMS $(\delta=0 \mathrm{ppm})$.

\section{RESULTS AND DISCUSSION}

\subsection{Effect of Phenol on Yield of and Composition of Obtained Oil}

In order to study the effect of phenol on the yield and the composition of the oil obtained by supercritical extraction with toluene, two series of experiments were carried out under the conditions described in the experimental part (section 2.2.1), with increasing volumes of toluene. The results obtained are given in Figure 2.

The shape of the two plots is the same, the mass of insoluble being lower in the case of the mixture (toluene + phenol) than for toluene alone. This shows that the addition of phenol increased the extraction yield without modifying the conditions of extraction by toluene, especially pressure. Figure 2 displays two zones of extraction, in the first one, the yield of recovery decreases with the increasing volume of toluene. A similar result was reported by Zhuang and Thies [39] during the supercritical extraction of petroleum pitch by toluene. They observed that the output of extraction was high for a solvent to pitch ratio equal to 2 and low for a ratio of 3 . This can be explained by repulsion forces between oil molecules in solution. In the second zone, the output of extraction increases as the volume of toluene grows.

At $390{ }^{\circ} \mathrm{C}$, the pressure in the autoclave reached 5.3 $\mathrm{MPa}$ and $7.5 \mathrm{MPa}$ for a volume of $50 \mathrm{~mL}$ and 70
$\mathrm{mL}$, respectively. In these conditions, toluene exceeds its critical point $\left(320^{\circ} \mathrm{C}, 4.2 \mathrm{MPa}\right)$, which confers it a good solvent capacity and consequently led to an increase in the output of extraction. Comparable results were obtained by Canel and Missal [40] on the extraction of oil shale of Gôynük (North-Western Turkey) by supercritical water. They concluded that the output of extraction increased as the pressure was increased.

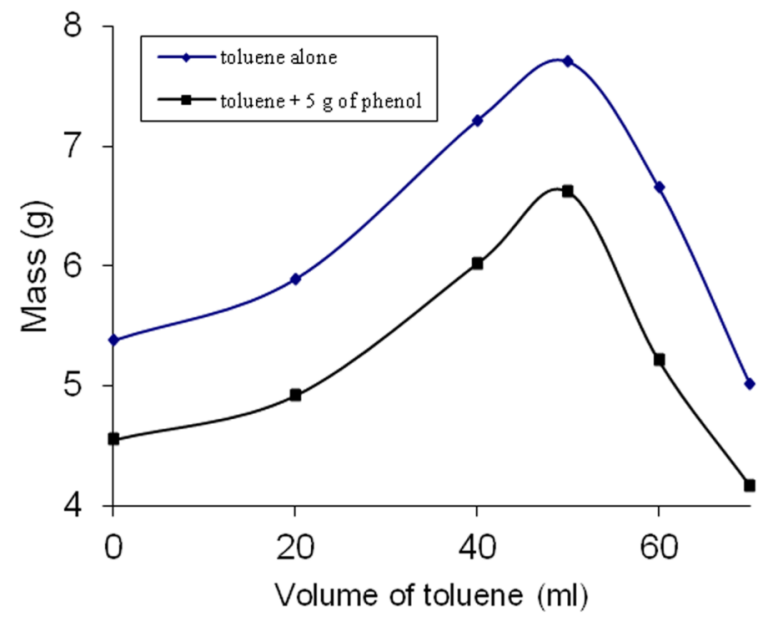

Figure 2: Variation of the insoluble material in $\mathrm{CHCl}_{3}$ as a function of the toluene volume.

As two extraction zones were identified above, two volumes of toluene were selected to study the effect of phenol on the extraction yield: $V_{1}=40 \mathrm{~mL}$ of toluene (zone 1) and $V_{2}=60 \mathrm{~mL}$ of toluene (zone 2).

The analysis of the results obtained (Figure 3) shows that the plots obtained in both cases have a similar shape and the weight of the insoluble material in chloroform decreases as the amount of phenol increases. It reaches its minimum for a mass of phenol

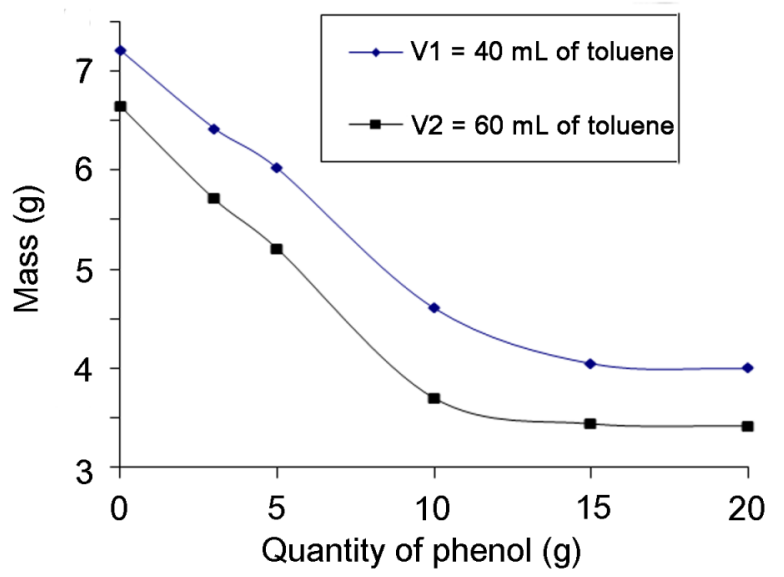

Figure 3: Variation of the insoluble material in $\mathrm{CHCl}_{3}$ as a function of the phenol mass. 
equal to $15 \mathrm{~g}$ in the first series of experiments $(40 \mathrm{~mL}$ of toluene) and $10 \mathrm{~g}$ for the second series of experiments ( $60 \mathrm{~mL}$ of toluene). Moreover, the mass of the insoluble material in chloroform is lower in the case of the second series of experiments.

In summary, the addition of phenol on oil extraction from Moroccan oil shale with supercritical toluene increases the extraction efficiency.

In view of SEC analysis results (Table 1), it appears that the value of the weight average molecular weight, $\bar{M}_{w}$ for the oil recovered by mixing toluene and phenol is, as expected, lower than that for the oil (HT70) obtained using toluene only.

Elemental analysis of the obtained oils (Table 2) showed that the oil HT70PH5 possesses a very low sulfur content and a higher aromaticity factor (low $\mathrm{H} / \mathrm{C}$ ) compared to HT70 oil. These results confirm the role of phenol as modifier of extraction with supercritical toluene in reducing the level of sulfur in oils extracted.

\subsection{Analyses of the Pitches}

\subsubsection{Analysis of the Pitches by SEC}

The results of the SEC analyses of the pitches are shown in Table 3 . The pitch obtained using $70 \mathrm{~mL}$ of toluene (PHT70) has a high value of $\bar{M}_{n}$, i.e. toluene is able to recover large molecules without degradation of kerogen. In contrast, in the case of extraction by mixing toluene and phenol, the $\bar{M}_{w}$ value obtained for the PHT70PH5 pitch is very low. This suggests that phenol has a degrading action, thus providing a pitch formed of low molecular weight molecules.

\subsubsection{TG/DTA}

The results of thermal analysis (TG/DTA) of the pitches (Figure 4) show that the pitch PHT70 is characterized by a mass loss that starts around $100{ }^{\circ} \mathrm{C}$ and ends at $550{ }^{\circ} \mathrm{C}$, with a peak around $420{ }^{\circ} \mathrm{C}$. The residue yield at $950{ }^{\circ} \mathrm{C}$ is about $32 \%$. Secondly, the thermogram of the pitch PHT70PH5 is completely different from the former. It exhibits a mass loss that spreads over the same temperature range as pitch PHT70, but with the appearance of a complex phenomenon consisting of 3 successive mass losses at $150{ }^{\circ} \mathrm{C}, 300{ }^{\circ} \mathrm{C}$ and $450{ }^{\circ} \mathrm{C}$. Furthermore, we note that the residue yield at $950{ }^{\circ} \mathrm{C}$ for this pitch $(36 \%)$ is somewhat higher than that of PHT70. This could be explained by the fact that the pitch PT70PH5 consists of lighter molecules but quite thermally stable compared to the pitch PHT70.

Table 1: Analysis of the Oils by SEC

\begin{tabular}{|c|c|c|c|}
\hline Oil & $\bar{M}_{w}^{a}$ & $\bar{M}_{n}^{b}$ & $I_{\mathrm{p}}{ }^{c}$ \\
\hline \hline HT70 & 1650 & 200 & 8.2 \\
\hline HT70PH5 & 1190 & 410 & 2.9 \\
\hline
\end{tabular}

${ }^{\mathrm{a}}$ Weight average molecular weight; ${ }^{\mathrm{b}} \mathrm{Number}$ average molecular weight. ${ }^{c} \mathrm{Ip}$ : polydispersity index $=\bar{M}_{w} / \bar{M}_{n} . \mathrm{HT70}$ : oil extracted using $70 \mathrm{~mL}$ of toluene. $\mathrm{HT70 \textrm {PH } 5 :}$ oil extracted using $70 \mathrm{~mL}$ of toluene $+5 \mathrm{~g}$ of phenol.

Table 2: Elemental Analysis of the Obtained Oils (wt\%)

\begin{tabular}{|c|c|c|c|c|c|}
\hline Fraction & C & H & N & S & O \\
\hline \hline HT70 & 41.09 & 53.7 & 0.056 & 1.2 & 4.06 \\
\hline HT70PH5 & 45.80 & 51.2 & 0.038 & 2.2 & 0.05 \\
\hline
\end{tabular}

(O was determined by difference). HT70: oil extracted using $70 \mathrm{~mL}$ of toluene. HT70PH5: oil extracted using $70 \mathrm{~mL}$ of toluene $+5 \mathrm{~g}$ of phenol.

Table 3: Analysis of the Pitches by SEC

\begin{tabular}{|c|c|c|c|}
\hline Oil & $\bar{M}_{w}^{a}$ & $\bar{M}_{n}^{b}$ & $I_{\mathrm{p}}{ }^{c}$ \\
\hline \hline PHT70 & 2670 & 230 & 11.6 \\
\hline PHT70PH5 & 1270 & 217 & 5.8 \\
\hline
\end{tabular}

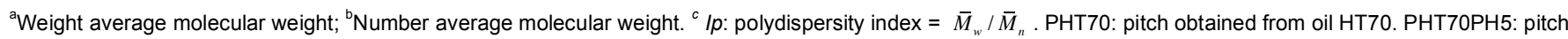
obtained from oil HT70PH5. 


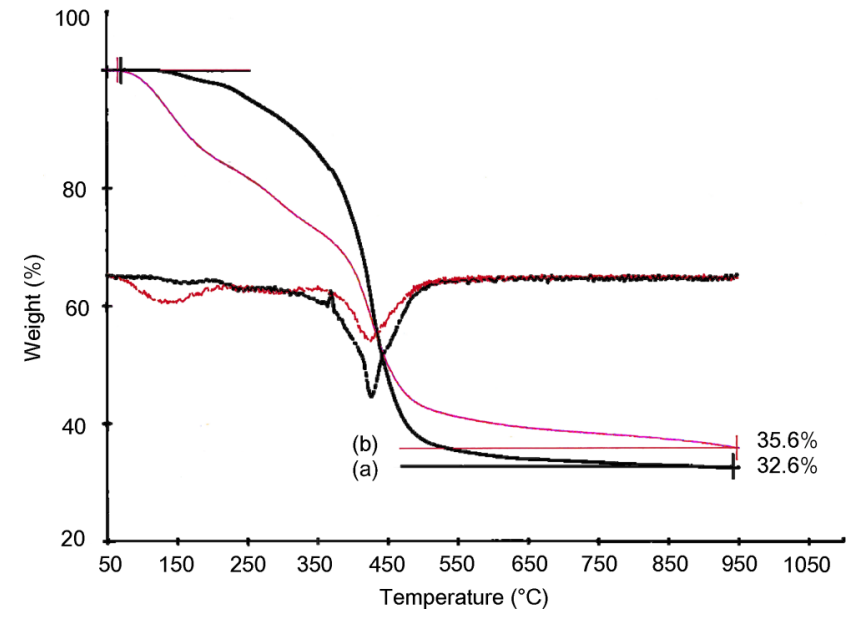

Figure 4: Thermograms of the pitches: (a) PHT70, (b) PHT70PH5.

\subsubsection{Elemental Analysis}

Elemental analysis of the obtained pitches (Table 4) showed that the pitch PHT70PH5 possessed a very low sulfur content and a higher aromaticity factor (low $\mathrm{H} / \mathrm{C}$ ratio) compared to pitch $\mathrm{PHT70}$.

Table 4: Elemental Analysis of the Pitches

\begin{tabular}{|c|c|c|c|c|c|}
\hline Pitch & C & H & N & S & $\mathbf{O}^{\mathbf{a}}$ \\
\hline \hline PHT70 & 42.3 & 52.6 & 1.09 & 1.7 & 2.26 \\
\hline PHT70PH5 & 45.17 & 48.6 & 0.88 & 1.34 & 3.99 \\
\hline
\end{tabular}

${ }^{\mathrm{a} O}$ is determined by difference. PHT70: pitch obtained from oil HT70. PHT70PH5: pitch obtained from oil HT70PH5.

\subsection{4. ${ }^{1} H$ NMR}

The pitches were also characterized by ${ }^{1} \mathrm{H}$ NMR spectroscopy (Figure 5). The spectrum of pitch PHT70 presents predominantly signals corresponding to aliphatic protons located between 0.5 and $3 \mathrm{ppm}$, while aromatic protons are very marginal. On the other hand, the spectrum of pitch PHT70PH5 reveals the presence of aliphatic and aromatic protons. Presumably, aromatic-rich compounds were extracted from heavy molecules in that case, which corroborates the results of the elemental analysis carried out on this pitch. This confirms that phenol was an efficient modifier likely to give a good yield of recovery and a better quality of oil.

\subsection{Characterization of the Filaments}

The carbonization yield at $950{ }^{\circ} \mathrm{C}$ was of about $49 \%$. Elemental analysis of the pyrolyzed filaments (C: 98.83; S: 1.08; Fe: 0.03 and Si: 0.06 in at.\%) showed that the organic matter extracted contained a minimum of metal impurities.

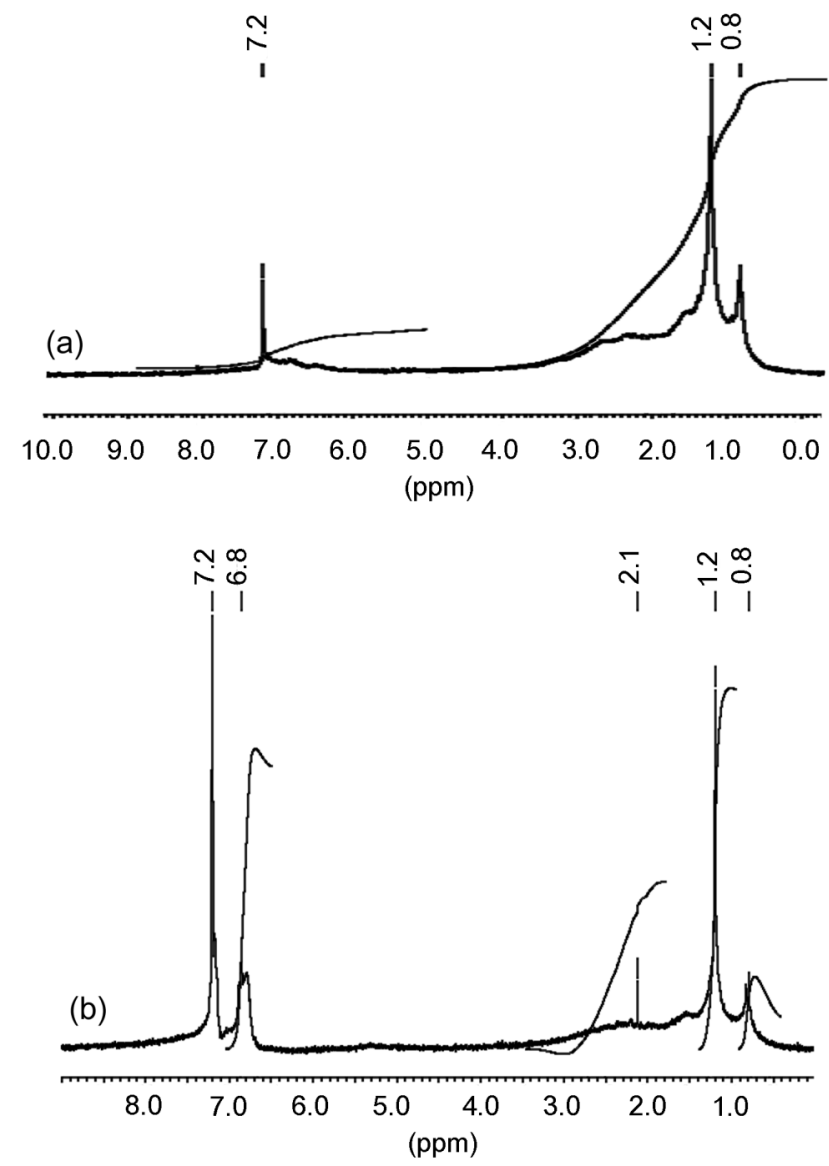

Figure 5: ${ }^{1} \mathrm{H}$ NMR spectra of the pitches: (a) PHT70, (b) PHT70PH5.

Mechanical tensile tests performed on monofilaments of about $20 \mu \mathrm{m}$ in diameter revealed a tensile strength of $320 \mathrm{MPa}$ and a Young's modulus of $30 \mathrm{GPa}$. These values are modest when compared to those found for fibers elaborated from precursors with oriented textures. They are, however, comparable to

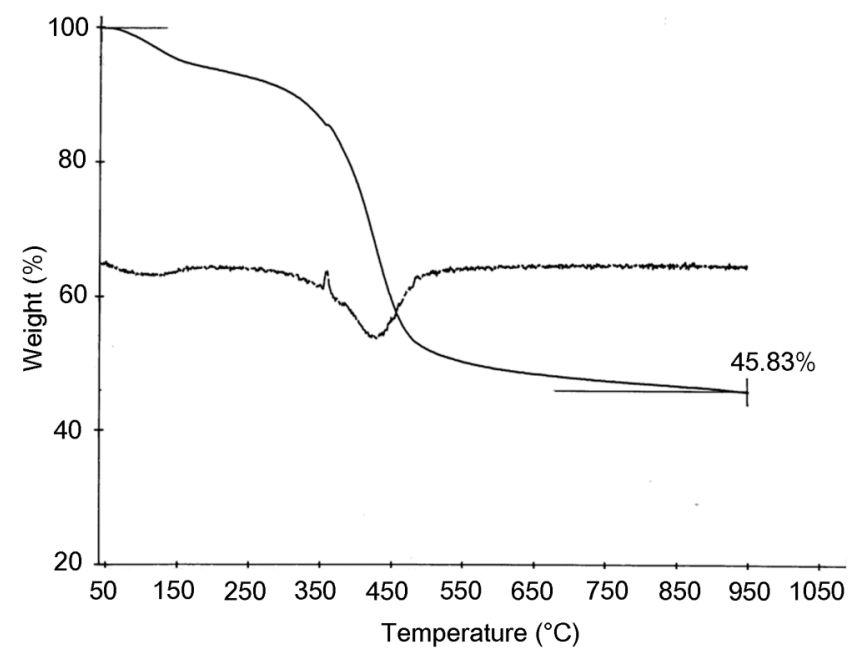

Figure 6: Thermal curve of the pitch PHT70PH5M. 

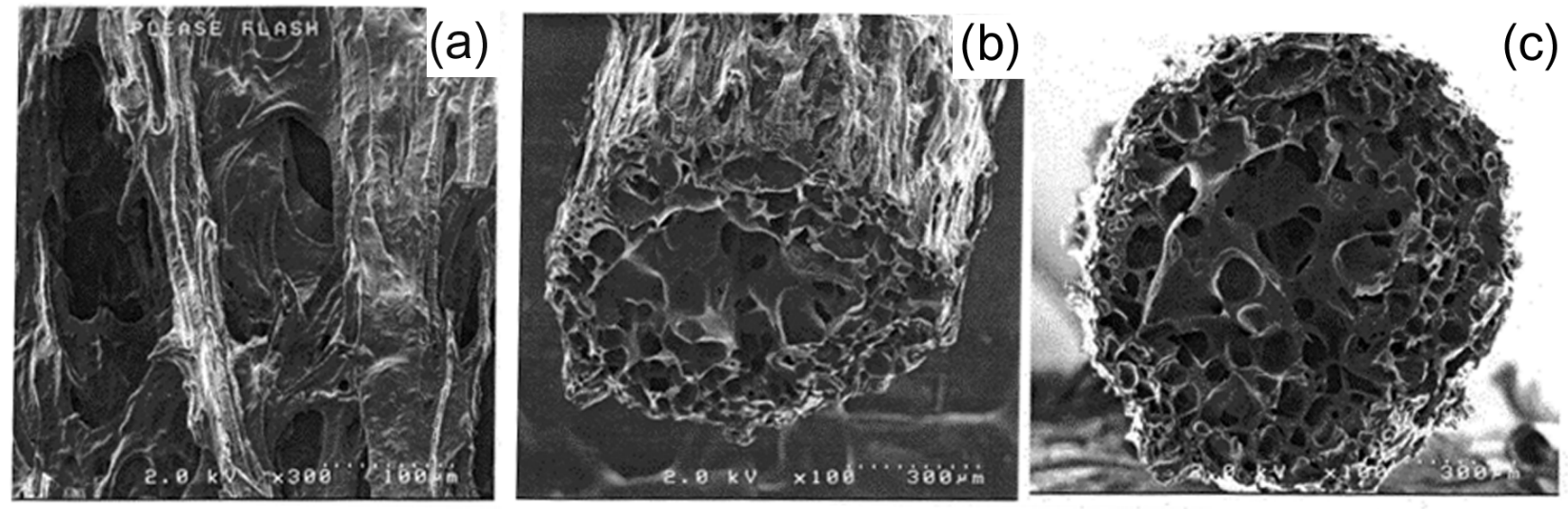

Figure 7: SEM micrographs of the stick.

those of fibers obtained from coal tar or petroleum isotropic pitches [41, 42].

In order to improve the mechanical properties of the fibers, we tried to increase the pitches softening temperature by adding a stage in their preparation. This step consisted firstly in precipitation of oils with ethanol followed by washing with hexane. This was intended for elimination of the majority of both light ends and polar functional groups since the presence or not of heteroatoms makes the materials obtained either crosslinkable or graphitizable [43]. Therefore, we used this method to prepare a new pitch from HT70PH5 oil. The softening temperature rose to $260^{\circ} \mathrm{C}$.

This new pitch (PHT70PH5M) was analyzed by TG/DTA (Figure 6) in order to compare the result with that of pitch PHT70PH5. The mass loss observed in Figure 4b between 180 and $300{ }^{\circ} \mathrm{C}$ for pitch PHT70PH5 (corresponding to molecules of low mass) has completely disappeared. We also noted an increase in the residual rate from $36 \%$ for $\mathrm{PHT} 70 \mathrm{PH} 5$ pitch to $46 \%$ for the new pitch PHT70PH5M. This result confirms that the new method of preparation of pitches leads to materials containing heavier molecules.

We tried to spin the new pitch as described in Section 2.2.2. The fibers obtained in this case were very thick, $d=850 \mu \mathrm{m}$, with a rod-like shape, probably because the spinning temperature is the decomposition temperature of the pitch. Furthermore, we noticed that these rods had a very important porous structure, thus analyses by SEM were performed (Figure 7). The SEM micrographs show highly porous structures. Figures $7 a$ and $\mathbf{7 b}$ show pores throughout the outer surface and Figure 7c shows the presence of pores in the heart of the stick. It therefore seemed to us very interesting to determine the specific surface area of these rods. To this end, nitrogen sorption measurements were conducted and values of the order of $300 \mathrm{~m}^{2} \mathrm{~g}^{-1}$ were found.

\section{CONCLUSIONS}

Within the framework of the development of Moroccan natural resources, we have carried out a study on Moroccan oil shale in order to prepare new pitches. The following conclusions can be drawn from the present investigation on the effects of phenol addition on oil extraction from Moroccan oil shale by supercritical toluene:

The oil yield obtained by toluene/phenol mixtures is significantly higher than that of oil extracted by toluene only.

The study of the influence of phenol on the extraction of organic matter from oil shale with toluene indicates that phenol plays a very important role in increasing the extraction efficiency of organic matter and a small change in mass of phenol results in a net increase in efficiency.

- $\quad$ The pitch prepared by mixing phenol and toluene contains more aromatics and a high residue rate at $950{ }^{\circ} \mathrm{C}$ compared to that obtained by extraction with supercritical toluene only.

Chemical modification of the pitches afforded very thick fibers with important porous surfaces, which suggest that their activation may result in activated carbon of good quality that might be used as adsorbent or filter in environmental applications.

\section{REFERENCES}

[1] Russel PL. Oil shales of the world, their origin, occurrence and exploitation, Pergamon Press, Oxford 1990. 
[2] Russel PL. An oil shale perspective. Min Eng 1981; 53: 2947.

[3] Ranney MW. Oil shale and tar sands technology, recent developments. Park Ridge, New Jersey, USA, 07656, 1979.

[4] Madec M, Espitalie J. Toarcian oil shale from the Paris basin. Rev Inst Fr Pet 1981; 24544.

[5] Veltsa O, Uibua M, Kallasa J, Kuusika R. Waste oil shale ash as a novel source of calcium for precipitated calcium carbonate: Carbonation mechanism, modeling, and product characterization. J Hazard Mater 2011; 195: 139-46. http://dx.doi.org/10.1016/j.jhazmat.2011.08.019

[6] Miao L, Ji G, Gao G, Li G, Gan S. Extraction of alumina powders from the oil shale ash by hydrometallurgical technology. Powder Technol 2011; 207: 343-7. http://dx.doi.org/10.1016/j.powtec.2010.11.017

[7] Sun T, Liu LL, Wan L, Zhang YP. Effect of silicon dose on preparation and coagulation performance of poly-ferricaluminum-silicate-sulfate from oil shale ash. Chem Eng J 2010; 163: 48-4. http://dx.doi.org/10.1016/j.cej.2010.07.037

[8] Gao GM, Miao LN, Ji GJ, Zou HF, Gan SC. Preparation and characterization of silica aerogels from oil shale ash. Mater Lett 2009; 63: 2721-4.

http://dx.doi.org/10.1016/j.matlet.2009.09.053

[9] Machado NR, Miotto DMM. Synthesis of $\mathrm{Na}-\mathrm{A}$ and $-\mathrm{X}$ zeolites from oil shale ash. Fuel 2005; 84: 2289-94. http://dx.doi.org/10.1016/j.fuel.2005.05.003

[10] Al-Qodah Z, Shawaqfeh AT, Lafi WK. Adsorption of pesticides from aqueous solutions using oil shale ash. Desalination 2007; 208: 294-5.

http://dx.doi.org/10.1016/j.desal.2006.06.019

[11] Abourriche A, Benhammou A, El hafiane $Y$, et al. Effects of oil shale addition on the microstructure and mechanical properties of porous ceramics from Moroccan raw clay. IOSR J Appl Chem 2015; 8: 13-21.

\section{http://dx.doi.org/10.9790/5736-08521321}

[12] Abourriche AK, Oumam M, Hannache $\mathrm{H}$, et al. Comparative studies on the yield and quality of oils extracted from Moroccan oil shale. J Supercrit Fluids 2013; 84: 98-4. http://dx.doi.org/10.1016/j.supflu.2013.09.018

[13] Abourriche A, Adil A, Oumam M, et al. New pitches with very significant maturation degree obtained by supercritical extraction of Moroccan oil shale. J Supercrit Fluids 2008; 47: 195-9.

http://dx.doi.org/10.1016/j.supflu.2008.07.016

[14] Martins MF, Salvador S, Thovert JF, Debenest G. Co-current combustion of oil shale - Part 2: Structure of the combustion front. Fuel 2010; 89: 133-43. http://dx.doi.org/10.1016/j.fuel.2009.06.040

[15] Aboulkas A, Makayssi T, Bilali L, El harfi K, Nadifiyine M, Benchanaa M. Co-pyrolysis of oil shale and plastics: Influence of pyrolysis parameters on the product yields. Fuel Process Technol 2012; 96: 209-13. http://dx.doi.org/10.1016/j.fuproc.2011.12.001

[16] Allawzi M, Al-Otoom A, Allaboun H, Ajlouni A, Al Nseirat F. $\mathrm{CO}_{2}$ supercritical fluid extraction of Jordanian oil shale utilizing different co-solvents. Fuel Process Technol 2011; 92: 2016-23. http://dx.doi.org/10.1016/j.fuproc.2011.06.001

[17] Fei Y, Marshall MC, Jackson WR, et al. Evaluation of several methods of extraction of oil from a Jordanian oil shale. Fuel 2012; 92: 281-7. http://dx.doi.org/10.1016/j.fuel.2011.08.019

[18] Al-Ayed OS, Suliman MR, Rahman NA, Kinetic modeling of liquid generation from oil shale in fixed bed retort. App Energ 2010; 87: 2273-7.

http://dx.doi.org/10.1016/j.apenergy.2010.02.006
[19] Fahmy TM, Paulaitis ME, Johnson DM, McNally MEP. Modifier effects in the supercritical fluid extraction of solutes from clay, soil, and plant materials. Anal Chem 1993; 65: 1462-9.

http://dx.doi.org/10.1021/ac00058a026

[20] John J, Hawthorms SB, Miller DJ, Pawllszym J. Role of modifiers for analytical-scale supercritical fluid extraction of environmental samples. Anal Chem 1994; 66: 909-16. http://dx.doi.org/10.1021/ac00078a024

[21] Lanças FM, Rissato SR. Influence of temperature, pressure, modifier, and collection mode on supercritical $\mathrm{CO}_{2}$ extraction efficiencies of Diuron from sugar cane and orange samples. J Microcolumn Sep 1998; 10: 473-8. http://dx.doi.org/10.1002/(SICl)1520667X(1998)10:6<473::AID-MCS2>3.0.CO;2-D

[22] Lanças FM, Queiroz MEC, Silva ICE. Seed oil extraction with supercritical carbon dioxide modified with pentane. Chromatographia 1994; 39: 687-92.

http://dx.doi.org/10.1007/BF02274584

[23] Lanças FM, Martins BS, Matta MHR. Supercritical fluid extraction (SFE) using an inexpensive 'home made' system. High Resol Chromatogr 1990; 13: 838-9. http://dx.doi.org/10.1002/jhrc.1240131210

[24] Lanças FM, Rissato SR, Galhiane MS. Supercritical fluid extraction of chlorothalonil residues from apples. Chromatographia 1996; 42: 323-8. http://dx.doi.org/10.1007/BF02290318

[25] Yang Y, Gharaibeh A, Hawthorne SB, Miller DJ. Combined temperature/modifier effects on supercritical $\mathrm{CO}_{2}$ extraction efficiencies of polycyclic aromatic hydrocarbons from environmental samples. Anal Chem 1995; 67: 641-6. http://dx.doi.org/10.1021/ac00099a023

[26] Luque de Castro MD, Tena MT. Strategies for supercritical fluid extraction of polar and ionic compounds. Anal Chem 1996; 15: 32-7.

http://dx.doi.org/10.1016/0165-9936(96)88035-6

[27] Hawthorne SB, Miller DJ, Nivenset DE, White DC. Supercritical fluid extraction of polar analytes using in situ chemical derivatization. Anal Chem 1992; 64: 405-12. http://dx.doi.org/10.1021/ac00028a015

[28] Oliveira JV, Vale MGR, Caramao EB. Supercritical Fluid. Extraction of a high-ash Brazilian coal. Fuel 1997; 76: 58591. http://dx.doi.org/10.1016/S0016-2361(97)00060-4

[29] Bjornbom PL, Bjornbom EP. Material losses in liquefaction of raw peat with carbon monoxide. Fuel 1987; 66: 779-84. http://dx.doi.org/10.1016/0016-2361(87)90124-4

[30] Cavalier JC, Chornet E. Fractionation of peat-derived bitumen into oil and asphaltenes. Fuel 1978; 57: 304-8. http://dx.doi.org/10.1016/0016-2361(78)90009-1

[31] Bekri O, Ziyad M. Synthesis of oil shale research and development activities in Morocco. In: Institute of Mining and Minerals Research editor. Proceedings of Eastern Oil Shale Symposium, Lexington, Kentucky, USA 1991; pp. 437-43.

[32] Abourriche A, Oumam M, Larzek M, Ichcho S, Hannache H, Pailler R, Naslain R, Birot M, Pillot JP. Elaboration et caractérisation des brais à partir des schistes bitumineux de Tarfaya (Maroc). Phys Chem News 2003; 11: 10-5.

[33] Yürüm $Y$, Kramer $R$, Levy $M$. Interaction of kerogen and mineral matrix of an oil shale in an oxidative atmosphere. Thermochim Acta 1985; 94: 285-93. http://dx.doi.org/10.1016/0040-6031(85)85272-2

[34] Rose HR, Smith DR, Vassallo AM. An investigation of thermal transformations of the products of oil shale demineralization using infrared emission spectroscopy. Energy Fuels 1994; 7: 319-25. http://dx.doi.org/10.1021/ef00038a024 
[35] Abourriche A, Oumam M, Hannache H, Pailler R, Naslain R, Birot M, Pillot JP. Influence du phénol, de la température et de la durée de traitement sur l'extraction supercritique de schistes bitumineux par le toluene. Phys Chem News 2003; 12: 93-101.

[36] Suatoni JC, Swab RE. Preparation of hydrocarbon type compounds analysis by high performance liquid chromatography. J Chromatogr Sci 1976; 14: 535-7. http://dx.doi.org/10.1093/chromsci/14.11.535

[37] Tissot B, Deroo G, Hood A. Geochemical study of the Inta basin: formation of petroleum from the Green River formation. Geo Cosmochim Acta 1978; 42: 1469-75. http://dx.doi.org/10.1016/0016-7037(78)90018-2

[38] Oumam M, Hannache H, Pailler R, Bourrat X, Naslain R. Elaboration de fibres de carbone à partir de schistes bitumineux. International Conference on Composites Materials in Architecture and Construction 1996; p. 101.
[39] Zhuang MS, Thies MC. Extraction of petroleum pitch with supercritical toluene: experiment and prediction. Energy Fuels 2000; 14: 70-5. http://dx.doi.org/10.1021/ef990141q

[40] Canel M, Missal P. Extraction of solid fuels with sub-and supercritical water. Fuel 1994; 73: 1776-80. http://dx.doi.org/10.1016/0016-2361(94)90167-8

[41] Donnet JB, Bausal RC. Carbon fibers, $2^{\text {nd }}$ Ed.; Marcel Dekker: New York 1990.

[42] Fitzer E, Heine M. In Bunsell AR. editor, Composites materials series. Elsevier, Amsterdam 1988; pp. 73-148.

[43] Oumam M, Hannache H, Pailler R, Bourrat X, Naslain R. Activated carbon fibers from Moroccan oil shales. in Martieau, P, Olivares $M$. editors. Proceedings of ARQUIMACOM'98, Bordeaux, France 1998; p. 113. 